\title{
Intertribal Timber Council survey of tribal research needs
}

\author{
by Chris Beatty ${ }^{1}$ and Adrian Leighton ${ }^{2}$
}

\begin{abstract}
This paper presents the results of the first systematic attempt to understand the research needs, priorities, and interests of Native American tribes' forest resource managers and decision-makers. In 2011 the Intertribal Timber Council disseminated a survey to 129 individuals that represented over 30 tribes as well as a variety of federal agencies and research/education institutions. The survey sought to evaluate the relative importance of a variety of research topic areas as well as better understand impediments to research faced by the tribes and evaluate the relative attractiveness of different opportunities for collaborations and partnerships. Results from the survey reveal three important themes: 1) tribes place particular importance on research related to water, fisheries and other "non-timber" values; 2 ) collaboration and cooperation are very important, especially concerning (but by no means limited to) the integration of traditional knowledge with western science; and 3) adaptation of research to the local landscape is of greater value than pursuing peer-reviewed, original research for its own sake. The findings of this survey will provide an important tool to the new ITC research subcommittee as it attempts to aid in the creation of culturally responsive, tribally driven forest-based research.
\end{abstract}

Key words: Native American Tribes, Tribal Research Survey, forest management, Intertribal, research collaboration and research needs

\section{RÉSUMÉ}

Cet article présente les résultats de la première tentative systématique de compréhension des besoins, des priorités et de l'intérêt vis-à-vis la recherche chez gestionnaires et les décideurs en matière de ressources forestières parmi les peuples autochtones de l'Amérique. En 2011, l'Intertribal Timber Council a distribué un sondage auprès de 129 personnes représentant plus de 30 tribus, ainsi que diverses agences fédérales et institutions de recherche ou de formation. Le sondage cherchait à évaluer l'importance relative de différents domaines de recherche ainsi quà mieux comprendre les obstacles reliés à la recherche rencontrés par les tribus et évaluer l'intérêt relatif des différentes opportunités de collaboration et de partenariat. Les résultats de ce sondage révèlent trois principaux thèmes : 1) les tribus accordent une importance particulière à la recherche portant sur l'eau, la pêche et les valeurs autres que celles reliées au bois; 2) la collaboration et la coopération sont très importantes, spécialement dans le cas (mais en aucun cas limité à) de l'intégration des connaissances traditionnelles aux sciences occidentales et 3) l'adaptation de la recherche à lenvironnement local est d'une plus grande valeur que la poursuite de travaux originaux en tant que tel soumis à une révision collégiale. Les résultats de ce sondage constitueront un outil précieux pour le nouveau sous-comité de recherche de l'ITC qui tente d’aider à la mise en place de travaux de recherche en foresterie adaptés à la culture et entrepris par les tribus.

Mots clés : peoples autochtones américains, sondage sur la recherche tribale, aménagement forestier, intertribal, collaboration en recherche et besoins de recherche

\section{Introduction}

Over the past several decades there have been two converging trends that have led to heightened awareness of the importance of Native American management of forests and other natural resources. The first is the growing trend within reservations across the United States toward self-determination, leading to forests and other resources managed not by the Bureau of Indian Affairs, but by the tribes themselves, in accordance with their values and objectives. The second is a growing recognition amongst the academic and management communities that management of all lands can benefit from seeking out Native perspectives, especially those founded in traditional knowledge systems (Kimmerer 2000, Alcoze 2003, Martinez 2003, Bengston 2004). Despite the increased capac- ity of tribally driven natural resource management, and the increased awareness of researchers regarding the importance of Native perspectives, there has been no attempt to directly gauge the research needs, priorities and interests of tribal resource managers and decision-makers.

In 2011, the Intertribal Timber Council (ITC), a consortium of 60 tribes and Alaska Native Corporations that manage forest resources, created a survey instrument as a means to begin the process of assessing and understanding research related needs and interests among tribal resource managers and decision-makers. A systematic method of this kind is the first in capturing the minds of Native indigenous leaders and important decision-makers managing these invaluable natural resources.

\footnotetext{
${ }^{1}$ Graduate Student, School of Environmental and Forest Sciences, University of Washington, Seattle, WA, USA. cbb7@uw.edu

${ }^{2}$ Forestry Professor, Department of Natural Resources, Salish Kootenai College, Pablo, MT. adrian_leighton@skc.edu
} 
The ITC has put in a great amount of effort pursuing important ways to protect and strengthen tribal communities and their natural resources, by facilitating collaborations involving communication, cooperation, and careful consideration amongst them, thus helping the tribes revitalize their practices (Morishima 1997). It has achieved important progress in promoting ecologically and economically sound management, collaborating with the BIA and other organizations that shared similar strategic goals. Among ITC's accomplishments is its role as a major contributor/facilitator to the development of the National Indian Forest Resource Management Act (NIFRMA), which among other things mandated an objective, third-party decadal review of the state of Indian forestry (Motanic 1998), and the Tribal Forest Protection Act of 2004, which enables tribes to identify projects on adjacent Forest Service or Bureau of Land Management lands that would reduce the risk of fire or forest health issues on tribal lands (Peterson and Erickson 2005). The ITC has also awarded thousands of dollars of scholarship funds for Native American students pursuing degrees in natural resource fields through its Truman D. Picard Jr. Memorial Scholarship. Another achievement was participation in the publication of the Tribal Wildfire Resource Guide, intended to provide an overview of federal forest/fire policies and authorities, federal fire planning programs and grant resources that may help tribes develop or strengthen fire management programs. This resource provides tribes with up-to-date information on the planning and prevention of wildfire, highlighting case studies from tribes around the United States that are actively engaged in planning or implementing fire-management programs (Resource Innovations 2006). Starting in 2010, ITC created a research subcommittee whose primary aim is to bring together a group of researchers, academicians and resource managers who can work together to enhance culturally responsive, tribally driven research that also supports Native students and scholars. The first task of this new subcommittee was to establish a deeper understanding of the research needs, obstacles and interests of tribal managers and leaders.

\section{Methods}

The subcommittee held its first meeting at the University of Washington in Seattle on the 8th of November, 2010 to discuss the structure of the survey and the types of questions to be used. The draft was established and a phone conference was held February 25, 2011 to further refine the questionnaire. The survey was divided into four parts: 1) participant information, primarily tribe/agency affiliation and occupation; 2) research topics; 3 ) impediments to access and use of research; and 4) participation in research activities. For each section, a list of factors or topics was listed, and participants were asked to rate the relative importance of each using a Likert rating scale from extremely important (5) to least important (1), thus creating an average importance score for each question. At the end of each survey section, an open-ended response box was provided to ensure that participants were not limited to the factors selected by the subcommittee. The survey was designed so that it could be made available in both a paper and online format. The survey was first presented on paper to workshop participants at the ITC Branding \& Marketing of Tribal Forest Products workshop held March 1-2, 2011, in Seattle Washington. E-mails were then sent out to tribal forest managers of all consortium tribes and other lead- ership contacts with a link to the online survey. All e-mail recipients were encouraged to share and forward the survey link to interested colleagues. Another "in place" opportunity for disseminating the survey took place at the American Indian Alaska Native Climate Change workshop held at the Salish-Kootenai College in Pablo, Montana on April 28th and $29^{\text {th }}, 2011$. Finally on March 29th, the link to the online questionnaire was posted on the ITC website. Common and significant trends and differences were analyzed, using them to provide recommendations for structure to improve natural resource and fire management, expanding social behavior and increasing economic benefits for tribal reservations.

\section{Results}

There were 129 participants (with a completion rate of $88 \%$ ) representing 31 different tribes, four tribal commissions or councils, one First Nation from British Colombia, three Universities or Colleges, four federal agencies and an independent engineering firm. Fifty-seven percent (73 responses) of the participants were tribal forest staff/managers, 25\% (32 responses) being other, which included members of non-BIA Federal land management agencies, ITC staff members, and academics. Next was students with $7.8 \%$ (11 responses representing 8 different schools), followed by tribal elected officials with $7.0 \%$ (9 responses), 6.3\% BIA staff (8 responses) and $1.6 \%$ tribal committee members (2 responses). Tribal committee members and tribal elected officials were later combined as a subgroup (8.6\% with 11 responses) (Fig. 1).

The Research Topics section listed a range of 21 topic areas that are the focus for research questions. These topic areas ranged from forest engineering, silviculture, to invasives, soil and water and the integration of traditional knowledge with western science. The aggregated survey results showed that water quality was of the most extreme importance with $54.9 \%$ (4.42 overall rating) of the survey participants overall assigning this topic a " 5 " (extremely important). Other important areas of research included fish and wildlife management at 44.7\% (4.24 overall rating), integration of traditional knowledge with western science at $47.4 \%$ (4.23 overall rating), and mechanisms to improve knowledge sharing among researchers and practitioners with $40.4 \%$ (4.06 overall rating). Invasive species rounded out the top five with a 3.92 overall rating (Fig.2).

Analysis of research topic priority by response group showed some variation in how the different topics were valued. There are some intriguing (though not statistically signif-

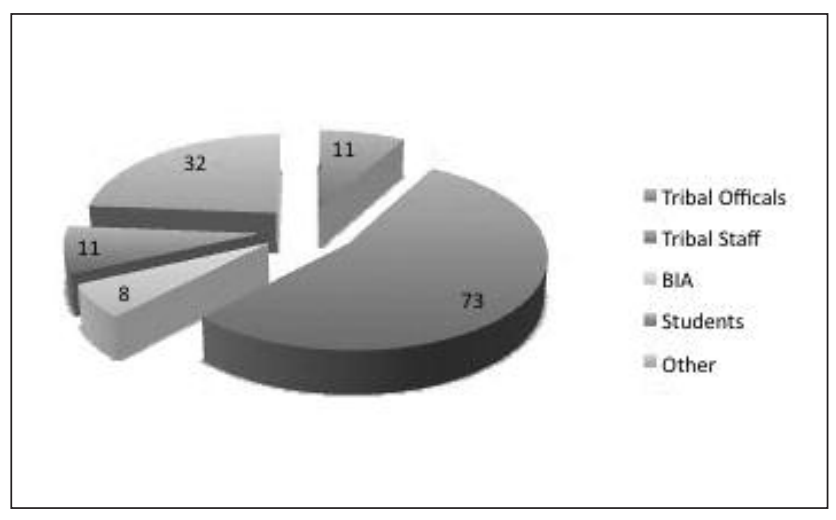

Fig. 1. Number of respondents by occupation. 


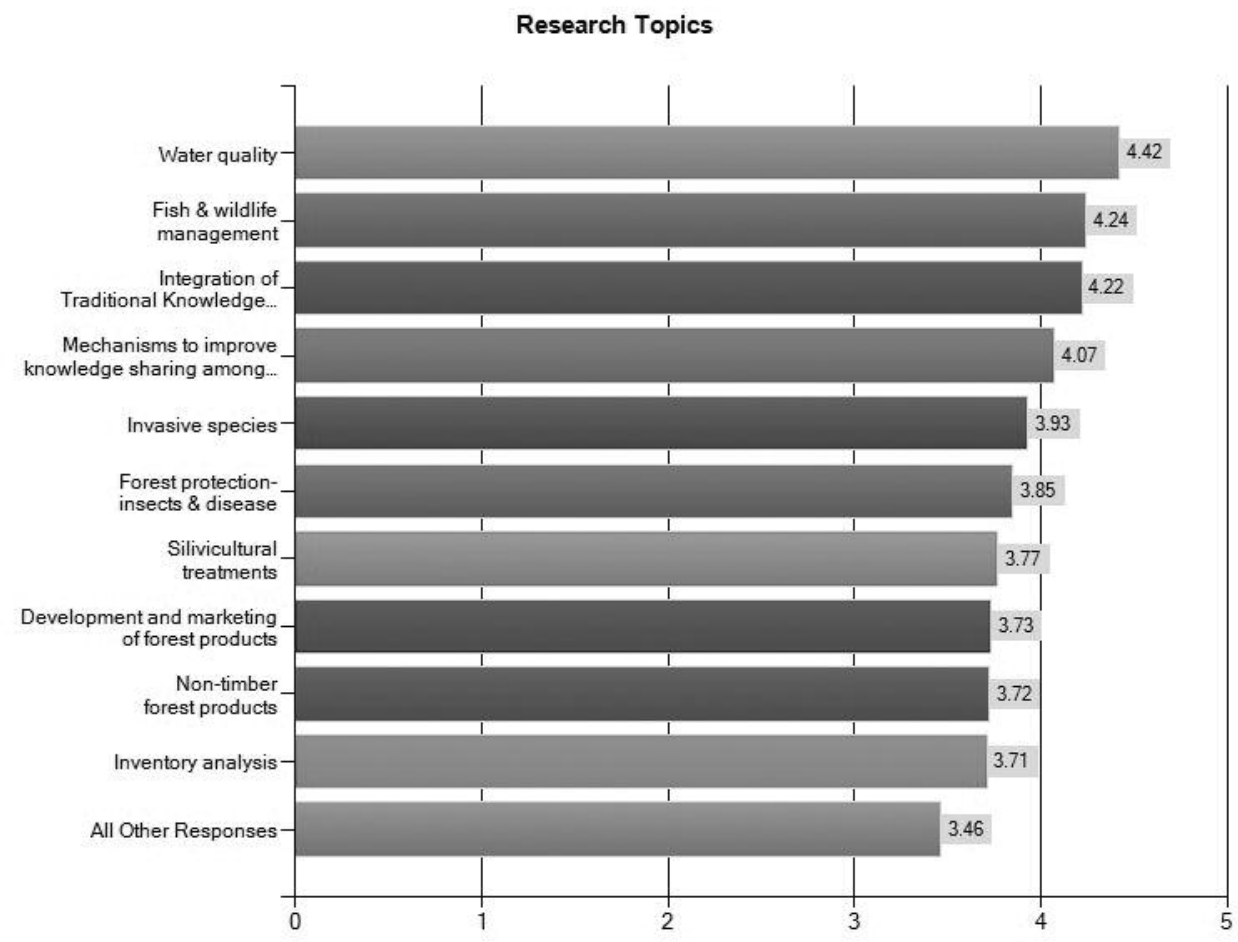

Fig. 2. Relative importance of various research topics.

Table 1. Top five research topic priorities chosen overall and their ratings by groups

\begin{tabular}{|c|c|c|c|c|c|c|}
\hline Research topics & Tribal officials & Tribal staff & BIA & Students & Other & Overall \\
\hline Water quality & 4.47 & 4.40 & 4.63 & 4.60 & 4.42 & 4.46 \\
\hline Fish and wildlife management & 4.45 & 4.33 & 4.25 & 4.30 & 4.13 & 4.23 \\
\hline Integration of traditional knowledge with western science & 4.00 & 4.13 & 3.75 & 4.5 & 4.48 & 4.22 \\
\hline Mechanisms to improve knowledge sharing & 3.89 & 3.80 & 4.25 & 4.06 & 4.06 & 4.06 \\
\hline Invasive species & 4.11 & 3.87 & 3.63 & 3.8 & 4.08 & 3.95 \\
\hline
\end{tabular}

icant at a 5\% confidence interval) differences between each category and how each of the response groups rated their level of importance. Tribal elected official and committee members placed a greater emphasis on topics related to financial returns , giving "development and marketing of forest products" their highest rating (4.64), followed by forest economics with a 4.28 rating. Decision-makers then ranked forest health third, with invasive species coming in fourth with a rating of 4.11 and wildland fire at 3.95 as the climate has begun to bring warmer temperatures, increasing insect infestation and drying out the forest, jeopardizing resources to a greater extent. Compared to management staff, tribal decision-makers placed a higher emphasis on forest engineering and forest genetics.

Tribal resource staff mirrored the aggregate results for the top three (water, fish and wildlife and integration of traditional knowledge) but then placed fourth-greatest emphasis on research for invasive species at a 3.87 rating and silvicultural treatments at a rating of 3.81. Management staff tended to place a higher emphasis on silvicultural research and forest mensuration/growth and yield than tribal decision-makers. For the BIA, fish and wildlife management had the same amount of emphasis as silvicultural treatments and mechanisms to improve knowledge-sharing among researchers and practitioners, all scoring a 4.25 rating. On the other hand, students and the "other" respondent group both rated integration of traditional knowledge and western science, and mechanisms to improve knowledge-sharing among researchers and practitioners as the second- and third-highest research priorities behind water quality. For students, fish and wildlife management rated fourth with a 4.3 rating, and wildland fire management and preparation for/adaptation to climate change impacts tied for fifth with a 4.1 average score. For the "other" group, invasive species and biomass/bioenergy tied for fifth (4.08 rating) (Fig.2; Table 1).

The third section of the survey focused on impediments to access and use of research. Respondents were asked to rate the 


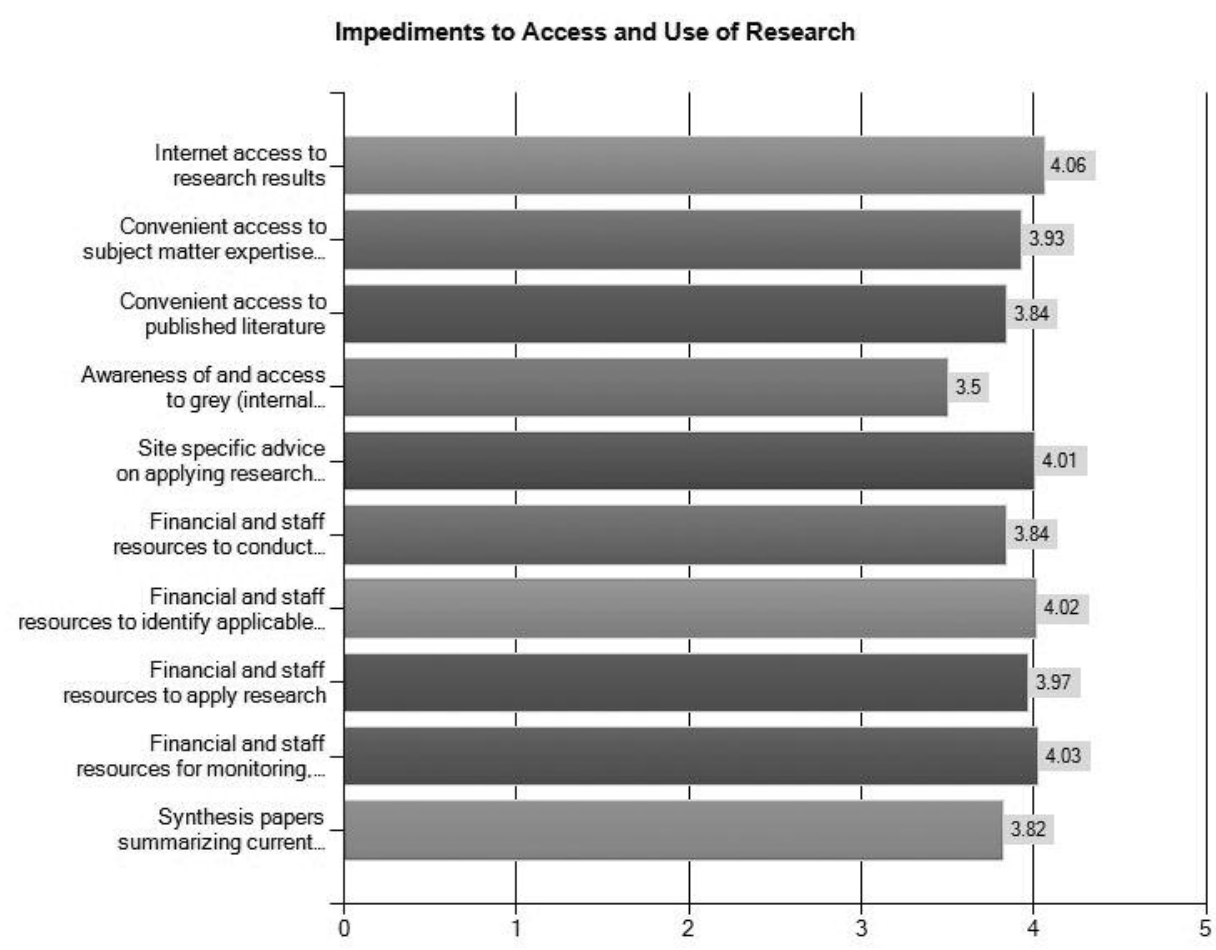

Fig. 3. Relative importance of possible impediments to research participation.

Table 2. Top four impediments to research for tribes overall and by groups

\begin{tabular}{|c|c|c|c|c|c|c|}
\hline Impediments to research access & Tribal officials & Tribal staff & BIA & Students & Other & Overall \\
\hline Internet access to research results & 4.25 & 4.13 & 4.50 & 3.80 & 4.04 & 4.08 \\
\hline Financial and staff resources to apply research & 4.07 & 4.00 & 4.13 & 4.00 & 4.28 & 4.06 \\
\hline $\begin{array}{l}\text { Financial and staff resources for monitoring, } \\
\text { evaluating and reporting results }\end{array}$ & 3.94 & 4.02 & 4.38 & 4.20 & 4.16 & 4.05 \\
\hline $\begin{array}{l}\text { Financial and staff resources to identify applicable } \\
\text { research to address local issues }\end{array}$ & 4.00 & 3.83 & 4.00 & 4.30 & 4.36 & 4.04 \\
\hline
\end{tabular}

relative importance of 10 potential obstacles to tribal research. Internet access to research results rated the highest, with $38.5 \%$ rating it of extreme importance (4.08 overall rating), followed closely by financial and staff resource to apply research at $37.9 \%$ (4.06 rating), financial and staff resources to identify applicable research to address local issues with $36.8 \%$ (4.04 rating) and site-specific advice to applying research to local conditions received the highest importance ranking from 31\% (4.06). There was much less emphatic agreement on the importance of the proposed obstacles than there was on the importance of certain research topics. Overall, there was very little spread between the different impediments. There was also a much closer alignment between all respondent groups than was seen in the first section of the survey (Fig. 3; Table 2).

The fourth and final section of the survey examined respondents' interest in participation in 11 different types of research activities. As with the previous section, none of the choices was significantly more important than the others, although "establishing research priorities" received both the highest score and the greatest number of "extremely important" designations (4.09 and $41.6 \%$ respectively). A three-way tie then follows between "securing financial and staff resources to apply research", "developing partnerships with research institutions", and "locating financial and staff resources for monitoring, evaluating and reporting results" all with a 3.81 overall rating. There was little overall emphasis placed on conducting original research or participating in the peer review process, with respondents focusing more on opportunities to apply research to local conditions and to monitor ongoing management activities. When comparing tribal decision-makers and tribal managers, the biggest difference between the two groups is the presentation of research results. The tribal officials placed a relatively high emphasis on this topic while tribal staff ranked it their lowest priority overall (Fig. 4; Table 3). 
Participation in Research Activities

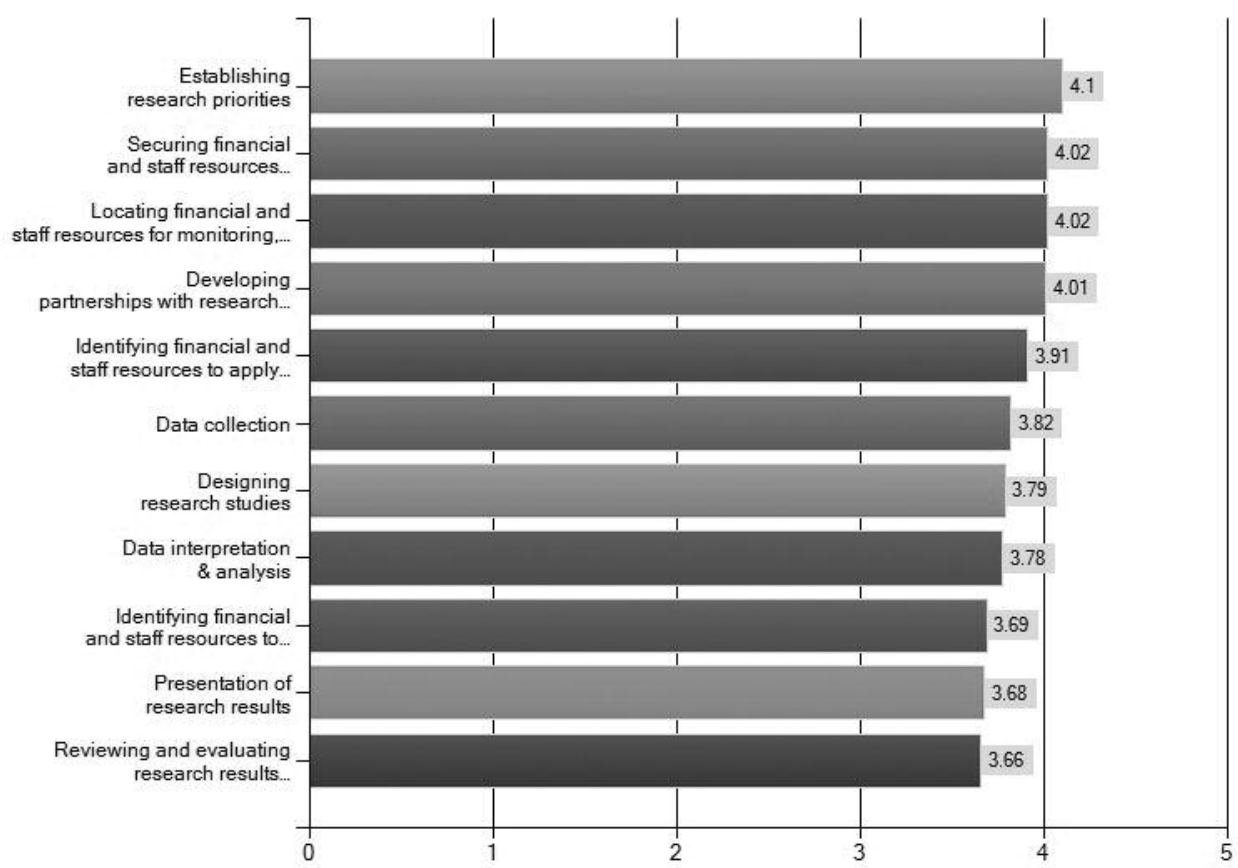

Fig. 4. Relative importance of various opportunities to participate in research.

Table 3. Top four areas of research participation overall and by groups

\begin{tabular}{|c|c|c|c|c|c|c|}
\hline Participation in research activities & Tribal officials & Tribal staff & BIA & Students & Other & Overall \\
\hline Establishing research priorities & 3.95 & 3.98 & 4.25 & 3.90 & 4.39 & 4.10 \\
\hline Securing financial and staff resources to apply research & 4.11 & 4.02 & 4.13 & 4.30 & 4.04 & 4.09 \\
\hline $\begin{array}{l}\text { Locating financial and staff resources for monitoring, } \\
\text { evaluating and reporting results }\end{array}$ & 3.70 & 3.96 & 4.38 & 3.90 & 4.22 & 4.04 \\
\hline Developing partnerships with research institutions & 3.70 & 3.85 & 4.25 & 4.50 & 4.13 & 4.03 \\
\hline
\end{tabular}

\section{Discussion and Conclusions}

This survey represents a first step in seeking out a better understanding of tribal natural resource managers' and decision-makers' interest, capacity and needs in research and engaging a meaningful dialogue that will lead to culturally sensitive and informed, tribally driven research. Many of the lessons learned here reflect what seem to be broader tribal values. Water, fish, wildlife and other "non timber" values take precedence when it comes to research priorities, echoing a more holistic, integrated view of natural resource management. Collaboration is also a major priority. While it is not surprising that integration of traditional knowledge with western scientific approaches is highly valued, there is also a recurring theme of relationship-building. Tribal managers, decision-makers and other respondents repeatedly identified the forging of relationships with research institutions and others. Communication with others and opportunities to meet and discuss are frequently valued over increased access to peer-reviewed literature. Collaborating with other agencies, research scientists, and the scholastic expertise of Native Americans attending tribal colleges and/or accredited universities to conduct research that integrate traditional ecological knowledge and western science has the potential to help all resource decision-makers adapt to an increasingly complex and changing world $\mathrm{A}$ focus on the local and a corresponding emphasis on applied research that translates published findings into on-the-ground techniques is also in keeping with a long-term tribal management perspective. Unlike many other forest management entities, Tribes represent an extremely long-term, place-based management model.

While general aggregated patterns do emerge, it is also worth noting that there may be important differences in perspective among the respondent groups. Students seem to think that integration of traditional knowledge with the west- 
ern scientific paradigm is of the highest importance, seconded by working with other researchers. Although fire, water, invasive species and forest health all ranked highly across respondent groups, students were the only ones to list adaptation and mitigation for climate change (which is frequently linked with all of these factors) within their top five research priorities. Tribal elected officials/committee members tended to emphasize topics that were related to increasing tribal economic, development, and health. Tribal managers, on the whole, seem to have more interest in adapting scholarly knowledge to applied local projects. They showed more focus on the condition of the environment, choosing water quality, wildlife, silviculture, and the integration of traditional ecological knowledge into western science as the most important research topics.

Some possible next steps that would broaden and deepen the explanatory power of this survey would include disseminating it to a wider tribal audience beyond the 31 tribes represented in the current survey and holding interviews or focus groups with tribal managers and officials to see if the survey list of impediments and participatory activities should be broadened or modified. Meanwhile, the lessons learned from this exercise will aid the ITC research committee as it moves forward in its attempt to help create a meaningful dialogue between tribes, agencies, universities and tribal scholars and students that will lead to a new paradigm of culturally responsive, tribally driven research.

\section{References}

Alcoze, T. 2003. First peoples in the pines. In P. Friederici (ed.). Ecological Restoration of southwestern ponderosa pine forests. Society for Ecological Restoration International. Island Press, Washington, DC.

Bengston, D.N. 2004. Listening to Neglected Voices: American Indian Perspectives on Natural Resource Management. Journal of Forestry 102(1): 48-52.

Kimmerer, R.W. 2000. Native knowledge for native ecosystems. Journal of Forestry 98(8): 4-9.

Martinez, D. 2003. Protected areas, indigenous peoples and the western idea of nature. Ecological Restoration 21: 247-250.

Motanic, D. 1998. The National Indian Forest Resources Management Act: What was and what will be. Evergreen Magazine (June): 26-27. Available at http://evergreenmagazine.com/magazine/article/The_National_Indian_Forest_Resources_Management_Act_W hat_Was_and_What_Will_Be.html.

Morishima, G.S. 1997. Indian Forestry: From Paternalism to SelfDetermination. Journal of Forestry 95(11): 4-9.

Resource Innovations. 2006. Tribal Wildfire Resource Guide. Developed in Partnership with Intertribal Timber Council. Available at https://scholarsbank.uoregon.edu/xmlui/bitstream/handle/1794/ 3647/twrg.pdf? sequence $=1$.

Peterson, J.G. and J.R. Erickson. 2005. Intertribal timber council launches Tribal Forest Protection Act with gusto. Evergreen Magazine (Winter 2005/2006): 50. Available at http://evergreenmagazine.com/magazine/article/Intertribal_Timber_Council_Laun ches_Tribal_Forest_Protection_act_wtih_Gusto_.html. 